\title{
Studying Customer Attitudes towards Advertising in Pakistan
}

\author{
Sheikh Aftab Ahmad ${ }^{1}$, Khalid Jamil2*, Muhammad Asghar Ali ${ }^{3}$ \\ ${ }^{1}$ University of Hail, Hail, Saudi Arabia \\ ${ }^{2}$ National University of Modern Languages (NUML) Islamabad, Pakistan \\ ${ }^{3}$ International Islamic University Islamabad, Pakistan \\ Aftab_ahmad@hotmail.co.uk, ${ }^{*}$ khalidjamil29@yahoo.com, asghariqbal68@yahoo.com
}

\begin{abstract}
The purpose of the paper is to examine the customer attitudes towards advertising in Pakistan. In this study researcher examine the different dimensions of attitudes towards advertising economics beliefs, social beliefs, regulation beliefs, and personal usefulness and ethics beliefs. Data for the study collected from the customers in twin cities of Pakistan. Final analysis performed on 116 valid responses. Cronbach's Alpha was used to check the reliability of the scale. Correlation and regression analysis was used to test the hypothesis and check the variance. The findings of the descriptive analysis shows that customer's regulation and ethics beliefs towards advertising are not better and Economic beliefs, Social beliefs and Personal usefulness about advertising are better. The current policies of advertisers are not according to customer's regulation beliefs and ethics beliefs. The data was collected just from students and used small sample of 116 respondents however it may effects to generality. The study provides significant practical implications for the marketing managers as well as advertisers to adjust their advertising plans or policies in Pakistan with respect to different dimensionality of consumer's attitudes toward advertising.
\end{abstract}

Keywords: Consumer's attitudes, advertising, social beliefs

\section{Introduction}

Advertising as a most important social event communicates a key changes in values, beliefs, behavior and buying patterns of the peoples which manipulate the lifestyles of people (Pollay \& Mittal, 1993). Munusamy and Wong (2007) mentioned that Attitude toward advertising is an interior concept and fundamentally is one of the determinants of attitude towards any specific advertisement (Lutz, 1985); attitude of the user or person towards a sole particular advertisement is predisposed by attitude towards general advertising (Bauer \& Greyser, 1968; Lutz, 1985). Tan and Chia (2007) quoted that researchers observes favorable or unfavorable attitude towards advertising. Advertising represents an important means by which organizations communicate with their customers, both current and potential (Bendixen, 1993). On one hand, attitudes toward advertising in general (defined as learned tendencies to respond in a consistently favorable or unfavorable manner to advertising in general) are major determinants of brand attitudes and purchase intentions (Lutz, 1985; MacKenzie \& Lutz, 1989). Hence, knowledge of public's predispositions towards advertising in general can yield insights into the effectiveness of advertising (Mehta, 2000). On the other hand, various publics' attitudes toward advertising shed light on the role of advertising as seen by diverse groups in a society and can potentially guide voluntary or mandatory corrective actions (Wills Jr \& Ryans Jr, 1982). Attitudes are conventionally regarded as an indicator of the effectiveness of advertising (Jun \& Lee, 2007). According to Mitchell and Olson (2000), an attitude towards an object is defined as an individual's internal evaluation based on his or her beliefs. Pakistan is considered as an emerging market; due to trends of globalization, establishment of multi-national companies; advertisement has undergone drastic changes in the recent years which has a great impact on the attitudes and beliefs of the consumer (Usman, Ilyas, Hussain, \& Qureshi, 2010). In 2007, spending on advertising was estimated at more than $\$ 385$ billion worldwide.

\section{Literature Review}

Attitudes towards Advertising: Lutz (1985) defined general attitudes toward advertising as an educated tendency to respond in a positive or adverse behavior to advertising in general. Consumers who consider advertising can create a constructive impact on the economy also have a tendency to more optimistic thoughts to advertising (Pollay \& Mittal, 1993). Sandage and Leckenby (1980) argue that thoughts to Advertising in general are highly optimistic than attitudes to real advertising and that consumer are less serious to economics beliefs in advertising than social beliefs in advertising. In this study we examine 
different dimensions of attitudes towards Advertising in Sargodha city of Pakistan. These dimensions are discussing below.

Economics beliefs in advertising: Consumers make decision better and easily due to advertising provide information about a product (Alwitt \& Prabhaker, 1992). Consumer has believed that advertising is main sources of information advertising (Siu \& Kai-ming Au, 1997). As McGuinness and Cowling (1975) explains, that consumer may be wrong informed when they search information about a product e.g. price location and qualities of product so their search cost is high then a firm advertise to provide information to consumer and reduce their search cost of product. Kaldor (1950) considers that advertising has indirect effects and economy of scale. He argues that advertising leads to more concentrated markets. Advertising may leads to lower price, if economies of scale are significant in production but if it crate brand loyalty so higher price.

H1: There is a significant, positive correlation between Economic beliefs and General attitude.

Social beliefs in advertising: Hunt and Arnett (2004)Says that there are two "social" criticisms, one is explicitly blame advertising with the influence to force to consumer buy product which they do not want or need and second is implicitly blame advertising with this power. Consumer may focus on attractive advertising and promote product in a positive manner for development of consumer's self -image (Richins, 1991). Mostly consumers are persuaded to buy a product they should not to purchase in real (Smith \& Andrews, 1989). Consumers purchase product to see famous logos, slogans add other corporate designs (Pollay \& Mittal, 1993). Although in primary this may seem logical, earlier research has actually designated that while the social role advertising plays is important; consumers generally do not trust advertising reveals their likeness.

H2: There is a significant, positive correlation between Social beliefs and General attitude.

Personal usefulness in advertising: Consumers make decision better and easily due to advertising provide information about a product (Alwitt \& Prabhaker, 1992).General attitudes to advertising have been forced by major dimensions or "personal uses" of advertising (Pollay \& Mittal, 1993) and distal background of advertising. The informative observation embrace that advertising mainly influences demand by conveying information. Bagwell (2007)stresses that advertising may generate brand loyalty and prevent entry. Kaldor (1950) progress the view more and strains that advertising guides to a more concentrated market, due to the occurrence of an advertising scale economy. Wills Jr and Ryans Jr (1982)argues that advertising typically presents slight information and is convincing in nature.

H3: There is a significant, positive correlation between Personal usefulness and General attitude.

Regulation beliefs in advertising: Advertising to children is extensively sighted as the factor of a progressively more commercialized culture (Kunkel \& Ford, 2005). Preschool audience is an important demographic group for building brand loyalty (Klein 1999). The second factor is that the childhood size rate is high in overall world. The children are mostly involves in food product's advertising so marketing of food products has significant relation with this problem (Kunkel \& Ford, 2005). In donating to diverse rules of advertising regulation, countries present their consumers various degrees of protection. Yet, as Kanter (1974) argues, regulations must be created according to customer's views. This argument suits especially effective in the environment of developing economies where the customer, frequently have a limited education and market knowledge, may be much less disbelieving of advertising (Cassim \& Langton, 1996).

H4: There is a significant, positive correlation between Regulation beliefs and General attitude.

Ethics beliefs in Advertising: The rise of ethical consumerism demonstrates that customers are gradually more ready to integrate ethics in their product buy decision. By "ethical" products, we pass on to products that display one or numerous social or environmental values which might influence consumer purchase decision. While a product cannot be ethical as such, it can be improved by ethical concerns or characteristics that are positively perceived (Crane, 2001). The advertising that mostly depends on children has been highly criticized for being controlling and for unfair benefit of children's unawareness. The advertising industry is struggling, with harsh calls for regulations and ethics in advertising. Sometimes it is appealing choice for government to controlling or banning advertising but government may serious in such issues even it may be useless to achieving the objectives set by policy maker (Eagle, Kitchen, \& Rose, 2005).

H5: There is a significant, positive correlation between Ethics beliefs and General attitude. 


\section{Methodology}

Research framework::This research is quantitative because researchers want to check the relationship of dependent and independent variables.

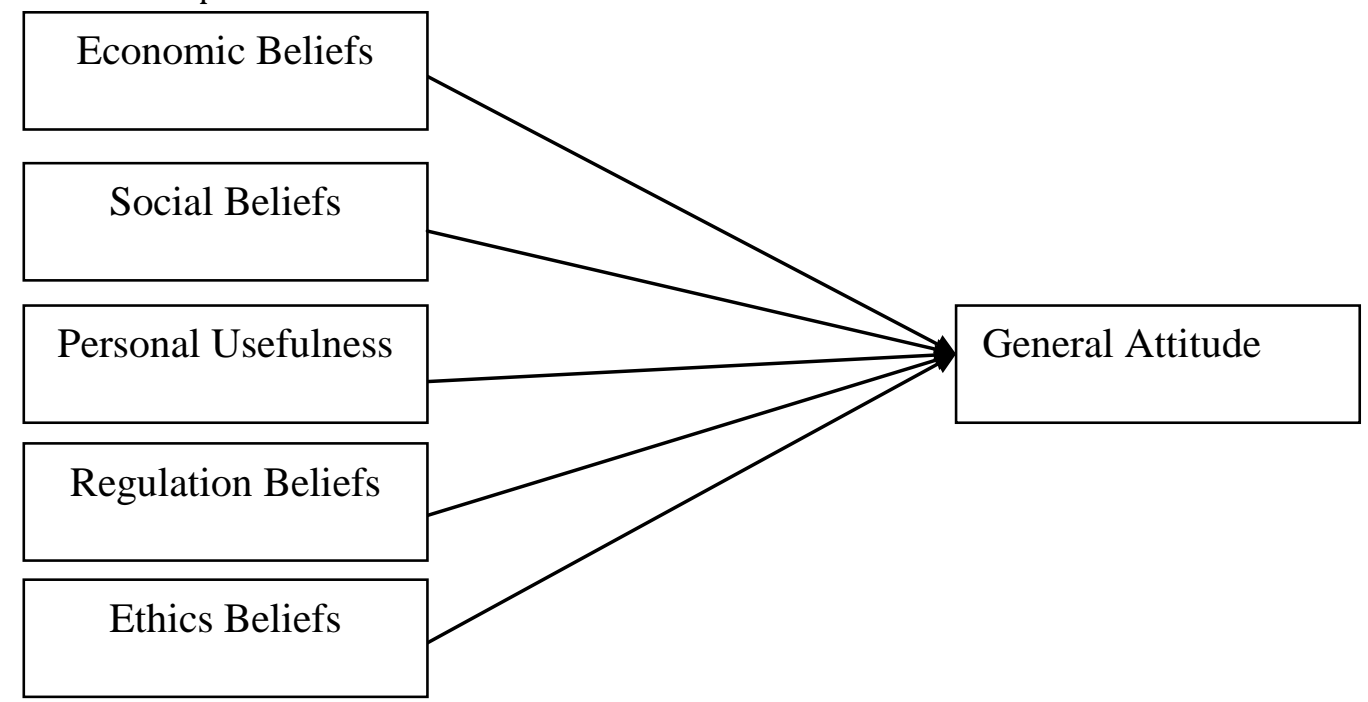

Sample: These study researchers are using the quantitative questionnaire. The questionnaires were filled from student of bachelors and masters program of University of Sargodha. Total 130 questionnaires were distributed among students, 120 were returned out of which final analysis adopted on 116 questionnaires. The 60 were males and 56 were females.

Instrument: The questionnaire used to check the relationship between the independent variables (Economics beliefs, Social beliefs, Personal usefulness, Regulations beliefs, Ethics beliefs) and dependent variable (General attitude).The questionnaire of likert scale ranges from $1=$ strongly disagree to $5=$ strongly agree was used and modified with the purpose of examine to the consumer attitudes towards advertising in general. The likert scale consisting of 20 items was adopted from (Wen-ling liu, 2002). General attitude has 3 items and independent variables, Economics beliefs has 3 items, Social beliefs has 2 items, Personal usefulness has 3 items, Regulation beliefs has 4 items and Ethics beliefs has 3 items. Total items are 18 in this research paper.

Data Analysis: The researchers used "Statistical Package for Social Science" Software to check the relationship of independent dimensions and dependent variable and reliability of questionnaire. Correlation and Regression analysis were used to test the hypotheses and variance. Comparison of means was used to examine the customer attitude towards different dimensions. Cranbach's Alpha was used to check the reliability of the scale which is (0.601) after deletion of 5 items (Hair, Anderson, \& Tatham). Multivariate Data Analysis, 5th ed, Prentice-Hall, Upper Saddle River, NJ).

\section{Results}

Table 1: Frequency Analysis

\begin{tabular}{ll}
\hline Gender of respondents & Frequency \\
\hline Male respondents & 64 \\
Female respondents & 54 \\
Total respondents & $\mathbf{1 1 6}$ \\
\hline
\end{tabular}


Table 2: Respondent's Age

\begin{tabular}{ll}
\hline Age of respondents & Frequency \\
\hline $17-19$ Years & 18 \\
$20-22$ Years & 84 \\
23 Years and above & 14 \\
Total & $\mathbf{1 1 6}$ \\
\hline
\end{tabular}

Tables 1 and 2 show that there are "116" total respondents in which "62" respondents are male and "54" are females and from those 18 respondent's age is between 17 to 19 years, 84 respondents are between 20 to 22 and 14 respondents are between 23 and above respectively.

\section{Descriptive Statistics}

Table3: Means

\begin{tabular}{lll}
\hline Dimensions & N & Mean \\
\hline Economics beliefs & 116 & 3.2299 \\
Social beliefs & 116 & 3.0733 \\
Personal usefulness & 116 & 3.5201 \\
Regulation beliefs & 116 & 2.4547 \\
Ethics beliefs & 116 & 2.9397 \\
General attitudes & 116 & 3.7586 \\
Valid N & $\mathbf{1 1 6}$ & \\
\hline
\end{tabular}

Table 3 shows the means of all the variables used. Most of the means show that people have a positive perception about the questions asked as mostly means are higher than 3 and 3 is considered as indifferent and after 3 there is agree and strongly agree options respectively. The mean 3 or more than 3 means that customers are satisfy through these dimensions towards advertising in general and less than 3 mean shows that customers are not satisfy through these dimensions towards advertising in general. The mean for economics beliefs is (3.2299), for social beliefs (3.0733), personal usefulness is (3.5201). The mean for regulation beliefs is (2.4547) and ethics beliefs (2.9397) which is low in respect of other variables. So its means that customers have different perceptions about these two variables and advertising in Sargodha is not according to customer's regulation and ethics values. Therefore advertiser has a dire need to focus on the regulation beliefs and ethics beliefs to satisfy the customer and has a need to adjust their advertising policies according to customer's regulation and ethics values.

Table 3 shows correlations among independent variables and their relationship with dependent variable. There is a positive and significant relationship between Economics beliefs and General attitude (.375). Personal usefulness has also positive and significant relationship with general attitude (.416). It means that these dimensions have positive impact on dependent variable. There is negative relationship of general attitude with social beliefs $(-.080)$, and regulation beliefs $(-.176)$. There is positive relationship between general attitude and ethics beliefs (.129) but not at significant level. Economic belief has a positive relationship with social beliefs (.059), personal beliefs (.176) and ethics beliefs (.110) but not at significant level and has a negative relationship with regulation beliefs $(-.044)$. Social belief has positive relationship with personal usefulness (.167), regulation beliefs (.139) and ethics beliefs (.021) but there is not at significant level. Personal belief has negative relationship with regulation beliefs $(-.203)$ and has a positive relationship with ethics beliefs (.097) but not at significant level. Regulation belief has positive and significant relationship with ethics beliefs (.206). On the basis of this the following hypothesis has been formulated:

H1: There is a significant, positive correlation between Economic beliefs and General attitude.

Table 4 indicates that there is a positive correlation $(r=0.375)$ between Economic beliefs and General attitude, which is significant at (0.000) level. Therefore $\mathrm{H} 1$ is accepted. 
H2: There is a significant, positive correlation between Social beliefs and General attitude.

Table 4 indicates that there is a negative correlation $(\mathrm{r}=-0.080)$ between Social beliefs and General attitude however it is not significant (0.396). Therefore $\mathrm{H} 2$ is not accepted.

H3: There is a significant, positive correlation between Regulation beliefs and General attitude.

Table 4 indicates that there is a negative correlation $(\mathrm{r}=-0.176)$ between Regulation beliefs and General attitude, however it is not significant at (0.059) level. Therefore H3 is not accepted.

H4: There is a significant, positive correlation between Personal usefulness and General attitude.

Table 4 indicates that there is positive correlation $(\mathrm{r}=-0.416)$ between Personal usefulness and General attitude which is significant at (0.000) level. Therefore $\mathrm{H} 4$ is accepted.

H5: There is a significant, positive correlation between Ethics beliefs and General attitude.

Table 4 indicates that there is a positive correlation ( $\mathrm{r}=0.129)$ between Ethics beliefs and General attitude, but it is not significant at (0.169) level. Therefore H5 is not accepted.

Table 4: Correlation

\begin{tabular}{|c|c|c|c|c|c|c|c|}
\hline & & $\begin{array}{l}\text { Social } \\
\text { beliefs }\end{array}$ & $\begin{array}{l}\text { General } \\
\text { attitude }\end{array}$ & $\begin{array}{l}\text { Ethics } \\
\text { beliefs }\end{array}$ & $\begin{array}{l}\text { Regulation } \\
\text { beliefs }\end{array}$ & $\begin{array}{l}\text { Personal } \\
\text { usefulness }\end{array}$ & $\begin{array}{l}\text { Economic } \\
\text { beliefs }\end{array}$ \\
\hline \multirow[t]{3}{*}{ Social beliefs } & $\begin{array}{l}\text { Pearson } \\
\text { correlation }\end{array}$ & 1 & -.080 & .021 & .139 & .167 & .059 \\
\hline & $\begin{array}{l}\text { Sig. } \\
\text { tailed })\end{array}$ & & .396 & .824 & .138 & .072 & .527 \\
\hline & $\mathrm{N}$ & 116 & 116 & 116 & 116 & 116 & 116 \\
\hline \multirow[t]{3}{*}{ General attitude } & $\begin{array}{l}\text { Pearson } \\
\text { correlation }\end{array}$ & -.080 & 1 & .129 & -.176 & $.416^{* *}$ & $.375^{* *}$ \\
\hline & $\begin{array}{l}\text { Sig. } \\
\text { tailed })\end{array}$ & .396 & & .169 & .059 & 0.000 & 0.000 \\
\hline & $\mathrm{N}$ & 116 & 116 & 116 & 116 & 116 & 116 \\
\hline \multirow[t]{3}{*}{ Ethics beliefs } & $\begin{array}{l}\text { Pearson } \\
\text { correlation }\end{array}$ & .021 & .129 & 1 & .206 & .097 & .110 \\
\hline & $\begin{array}{l}\text { Sig. } \\
\text { tailed })\end{array}$ & .824 & .169 & & .026 & .301 & .240 \\
\hline & $\mathrm{N}$ & 116 & 116 & 116 & 116 & 116 & 116 \\
\hline \multirow[t]{3}{*}{$\begin{array}{l}\text { Regulation } \\
\text { beliefs }\end{array}$} & $\begin{array}{l}\text { Pearson } \\
\text { correlation }\end{array}$ & .139 & -.176 & .206 & 1 & $-.203^{*}$ & -.044 \\
\hline & $\begin{array}{l}\text { Sig. } \\
\text { tailed })\end{array}$ & .138 & .059 & .026 & & .029 & .642 \\
\hline & $\mathrm{N}$ & 116 & 116 & 116 & 116 & 116 & 116 \\
\hline \multirow[t]{3}{*}{$\begin{array}{l}\text { Personal } \\
\text { usefulness }\end{array}$} & $\begin{array}{l}\text { Pearson } \\
\text { correlation }\end{array}$ & .167 & $.416^{* *}$ & .097 & $-.203^{*}$ & 1 & .176 \\
\hline & $\begin{array}{l}\text { Sig. } \\
\text { tailed })\end{array}$ & .072 & .000 & .301 & .029 & & .058 \\
\hline & $\mathrm{N}$ & 116 & 116 & 116 & 116 & 116 & 116 \\
\hline \multirow[t]{3}{*}{ Economic beliefs } & $\begin{array}{l}\text { Pearson } \\
\text { correlation }\end{array}$ & .059 & $.375^{* *}$ & .110 & -.044 & .176 & 1 \\
\hline & $\begin{array}{l}\text { Sig. } \\
\text { tailed })\end{array}$ & .527 & .000 & .240 & .642 & .058 & \\
\hline & $\mathrm{N}$ & 116 & 116 & 116 & 116 & 116 & 116 \\
\hline \multicolumn{8}{|c|}{ **. Correlation is significant at the 0.01 level (2-tailed). } \\
\hline
\end{tabular}


Table 5: Model Summary

\begin{tabular}{llllllll}
\hline Model & $\mathbf{R}$ & $\begin{array}{l}\mathbf{R} \\
\text { Square }\end{array}$ & $\begin{array}{l}\text { Adjusted } \\
\text { Square }\end{array}$ & $\begin{array}{l}\text { R } \\
\text { Std. Error of the } \\
\text { Estimate }\end{array}$ & $\begin{array}{l}\text { Durbin- } \\
\text { Watson }\end{array}$ & F & Sig. \\
\hline 1 & $.550^{\mathrm{a}}$ & .303 & .271 & .55987 & 1.935 & 9.561 & $.000^{\mathrm{a}}$ \\
\hline
\end{tabular}

The results in Table 5 indicates that there is a positive correlation (R: 0.550 ) between the independent (economics beliefs, social beliefs, regulation beliefs, personal usefulness \& ethics beliefs) and dependant variable (general attitude). The value of Durbin-Watson statistic (1.935) is also within acceptance range which indicates that there is no autocorrelation among the variables. In the Table the value for Adjusted $\mathrm{R}$ Square $(0.271$ ) shows that the independent variables (economics beliefs, social beliefs, regulation beliefs, personal usefulness \& ethics beliefs) explain $27.1 \%$ variance in dependant variable (general attitude).Similarly it also shows that the F statistic value of 9.561 is significant at 0.000 level.

Table 6: Coefficients

\begin{tabular}{|c|c|c|c|c|c|}
\hline & \multicolumn{2}{|c|}{$\begin{array}{l}\text { Unstandardized } \\
\text { Coefficients }\end{array}$} & \multicolumn{2}{|c|}{$\begin{array}{l}\text { Standardize } \\
\text { Coefficients }\end{array}$} & \multirow[b]{2}{*}{ Sig. } \\
\hline & B & Std. error & Beta & $\mathbf{T}$ & \\
\hline (constant) & 2.009 & .442 & & 4.543 & .000 \\
\hline Economics beliefs & .305 & .081 & .307 & 3.778 & .000 \\
\hline Social beliefs & -.118 & .065 & -.148 & -1.805 & .074 \\
\hline Regulation beliefs & -.084 & .084 & -.085 & -1.000 & .319 \\
\hline Personal usefulness & .321 & .075 & .362 & 4.264 & .000 \\
\hline Ethics beliefs & .069 & .071 & .80 & .973 & .333 \\
\hline
\end{tabular}

Dependent Variable-General attitude: In the table6 the Beta values for economics beliefs, (0.307) and Personal usefulness, (0.362) are significant at 0.000 levels than Social beliefs, regulation beliefs and ethics beliefs. It's means that Economics beliefs and Personal usefulness are most important for advertising agencies. The minor changes in these two dimensions will bring a huge change in response of customer attitude towards advertising.

\section{Discussion}

- There is a positive and significant relationship between economics beliefs and general attitude and same relationship personal beliefs and general attitude.

- The findings of the descriptive analysis shows that customer's regulation and ethics beliefs towards advertising are not better and Economic beliefs, Social beliefs and Personal usefulness about advertising are better.

- This study shows that customers are satisfy with general attitude towards the advertising through Economics beliefs and personal usefulness beliefs.

- Customers are not satisfied with general attitude towards advertising through three dimensions social beliefs, regulation beliefs and ethics beliefs.

- The empirical research shows that there is a positive correlation between independent variable (Economics beliefs, Personal usefulness) and dependent variable (General attitude).

- Therefore hypothesis $\mathrm{H} 1$ and $\mathrm{H} 4$ are accepted and hypothesis H2, H3 and H5 are not accepted.

- Its means that consumer's perceptions about Social, Regulation and Ethics beliefs towards advertising in Sargodha are not positive and consumer's perception about Economic beliefs and Personal usefulness towards advertising in Sargodha are positive.

- The current policies of advertisers are not according to customer's regulation beliefs and ethics beliefs.

\section{Conclusion}

However, the study found that personal usefulness in advertising is the most important dimension among independent variables (economics beliefs, social beliefs, regulation beliefs, personal usefulness, ethics beliefs) 
effecting consumer attitudes toward advertising in Sargodha. All dimensions are very important but economics beliefs and personal beliefs have a positive and significant relationship with general attitude towards advertising and all dimensions have a direct impact on customer satisfaction but minor changes in economics and personal usefulness beliefs brings huge changes in satisfaction of customers and attitude towards advertising. These dimensions are very important for examine the satisfaction of customers and their attitudes towards advertising. The impact of this research is very positive for advertisers.

Limitations: This is very popular research area in Pakistan and there is more research on this topic. The research was carried out only in Sargodha city. The data was collected just from students and used small sample of 116 respondents however it may effects to generality.

Recommendations: According to research results the advertisers have a need to adjust their advertising policies according to advertising regulation and ethics due to customers are not satisfy with advertising regulation, ethics and advertising to children as you know that media has changed culture in Pakistan. Advertising regulation authority has needed to make proper advertising planning about rules and most important is implementations in this sector. Regulation Authority must keep in mind all negative effects of bad advertising to make advertising rules and should bane illegal Advertising. The top management of all Advertising organizations should follow all rules and regulations of customer or audience ethics.

\section{References}

Alwitt, L. F. \& Prabhaker, P. R. (1992). Functional and belief dimensions of attitudes to television advertising: Implications for copytesting.

Bagwell, K. (2007). The economic analysis of advertising. Handbook of industrial organization, 3, 1701-1844.

Bauer, R. A. \& Greyser, S. A. (1968). Advertising in America, the consumer view.

Bendixen, M. T. (1993). Advertising effects and effectiveness. European Journal of Marketing, 27(10), 19-32.

Cassim, S. \& Langton, R. (1996). Current issues in the regulation of deceptive advertising: Some consequences for South Africa. South African Journal of Business Management, 27(4), 82-88.

Crane, A. (2001). Unpacking the ethical product. Journal of Business Ethics, 30(4), 361-373.

Eagle, L., Kitchen, P. J. \& Rose, L. (2005). Defending brand advertising's share of voice: A mature market (s) perspective. The Journal of Brand Management, 13(1), 65-79.

Hair, J., Anderson, R. \& Tatham, R. Black. WC (1998). Multivariate data analysis, 5.

Hunt, S. D. \& Arnett, D. B. (2004). Market segmentation strategy, competitive advantage, and public policy: Grounding segmentation strategy in resource-advantage theory. Australasian Marketing Journal (AMJ), 12(1), 7-25.

Jun, J. W. \& Lee, S. (2007). Mobile media use and its impact on consumer attitudes toward mobile advertising. International Journal of Mobile Marketing, 2(1).

Kaldor, N. (1950). The economic aspects of advertising. The review of economic studies, 18(1), 1-27.

Kanter, D. L. (1974). Research on the effects of over-the-counter drug advertising. Journal of Drug Issues, 4(3), 223-226.

Kunkel, D. \& Ford, J. (2005). Predicting a renaissance for children and advertising research. International journal of Advertising, 24(3), 401-405.

Lutz, R. J. (1985). Affective and cognitive antecedents of attitude toward the ad: A conceptual framework. Psychological processes and advertising effects, 3, 45-64.

MacKenzie, S. B. \& Lutz, R. J. (1989). An empirical examination of the structural antecedents of attitude toward the ad in an advertising pretesting context. The Journal of Marketing, 4, 48-65.

McGuinness, T. \& Cowling, K. (1975). Advertising and the aggregate demand for cigarettes. European Economic Review, 6(3), 311-328.

Mehta, A. (2000). Advertising attitudes and advertising effectiveness. Journal of advertising research, 40(3), 67-72.

Mitchell, A. A. \& Olson, J. C. (2000). Are product attribute beliefs the only mediator of advertising effects on brand attitude? Advertising \& Society Review, 1(1).

Munusamy, J. \& Wong, C. H. (2007). Attitude towards advertising among students at private higher learning institutions in Selangor. Unitar E-journal, 3(1), 31-51. 
Pollay, R. W. \& Mittal, B. (1993). Here's the beef: factors, determinants, and segments in consumer criticism of advertising. The Journal of Marketing, 3, 99-114.

Richins, M. L. (1991). Social comparison and the idealized images of advertising. Journal of Consumer Research, 18(1), 71-83.

Sandage, C. H. \& Leckenby, J. D. (1980). Student attitudes toward advertising: Institution vs. instrument. Journal of Advertising, 9(2), 29-44.

Siu, W. S. \& Kai-ming-Au, A. (1997). Women in advertising: A comparison of television advertisements in China and Singapore. Marketing intelligence \& planning, 15(5), 235-243.

Smith, W. F. \& Andrews, R. L. (1989). Instructional leadership: How principals make a difference: ERIC.

Tan, S. J. \& Chia, L. (2007). Are we measuring the same attitude? Understanding media effects on attitude towards advertising. Marketing Theory, 7(4), 353-377.

Usman, M., Ilyas, S., Hussain, M. F. \& Qureshi, T. M. (2010). General attitude towards advertising: Cultural influence in Pakistan. International Journal of Marketing Studies, 2(2), 124.

Wills Jr, J. R. \& Ryans Jr, J. K. (1982). Attitudes toward advertising: A multinational study. Journal of International Business Studies, 13(3), 121-129. 